\title{
PRAIAS
}

\section{SÉRGIO ALCIDES*}

SÉRGio AlCIDES (Rio de Janeiro, 1967) é autor de Píer (São Paulo: Editora 34, 2012), entre outros livros de poesia. É professor da Faculdade de Letras da UFMG, fellow em 2013 do Centro Bellagio (Fundação Rockefeller) e do Instituto Sacatar, em 2004. Como tradutor de poesia, publicou livros e poemas avulsos de poetas como Ted Hughes, Juan Gelman, Alejandra Pizarnik, Joan Brossa, José Ángel Valente, Jules Supervielle e Philippe Jaccotett, entre outros.

\section{BEACHES}

SÉRGIO ALCIDES (Rio de Janeiro, 1967) is the author of Pier (São Paulo: Editora 34, 2012), among other poetry books. He is a Professor at the Faculdade de Letras of UFMG (School of Literature and Languages of the Federal University in Minas Gerais), a Rockfeller Foundation Centro Bellagio fellow in 2013, and an Instituto Sacatar fellow in 2004. As poetry translator, he published books and sporadic poems by poets such as Ted Hughes, Juan Gelman, Alejandra Pizarnik, Joan Brossa, José Ángel Valente, Jules Supervielle, and Philippe Jaccotett, among others.

*Faculdade de Letras - Universidade Federal de Minas Gerais

Email: sergioalcides@letras.ufmg.br

Recebido em 4/12/2015. Aprovado em 4/12/2015. 
Sobre estas praias o Ocidente se pôs.

A luz ofusca, pode-se aqui

notar que o Sol é que

é o centro do universo

e não esta terra.

É preciso descobrir que alternativas

raramente são nativas

em qualquer lugar.

Não tem original,

também os aborígenes viajaram,

este é um poema

em tradução.

Só que um poema

é violência.

Não se pode escrever nós.

Pelo menos não se pode

querer mesmo dizer

o que, se dizem nós,

já quer dizer eles.

Porque nós é violência.

Tem tanta cor,

fica difícil distinguir o preto do branco.

Não, talvez, em preto-e-branco.

Nos falta uma lente, um olho

estranho, que nos arranje

em outra imagem

e semelhança.

Só que uma lente

é violência. 